\title{
PENGARUH PERILAKU KEPEMIMPINAN DAN BUDAYA ORGANISASI TERHADAP KINERJA KARYAWAN DI PT. INDONESIA POWER - PLTU JERANJANG LOMBOK
}

\author{
Melky Victor Borsalino', Surati², Sri Wahyulina ${ }^{3}$ \\ 1Program Studi Magister Manajemen Fakultas Ekonomi dan Bisnis Unram \\ Email: mv_borsalino@yahoo.co.id \\ ${ }^{2}$ Fakultas Ekonomi dan Bisnis Unram \\ Email: drsurati2013@gmail.com \\ ${ }^{3}$ Fakultas Ekonomi dan Bisnis Unram \\ Email: ssriwahyulina@gmail.com
}

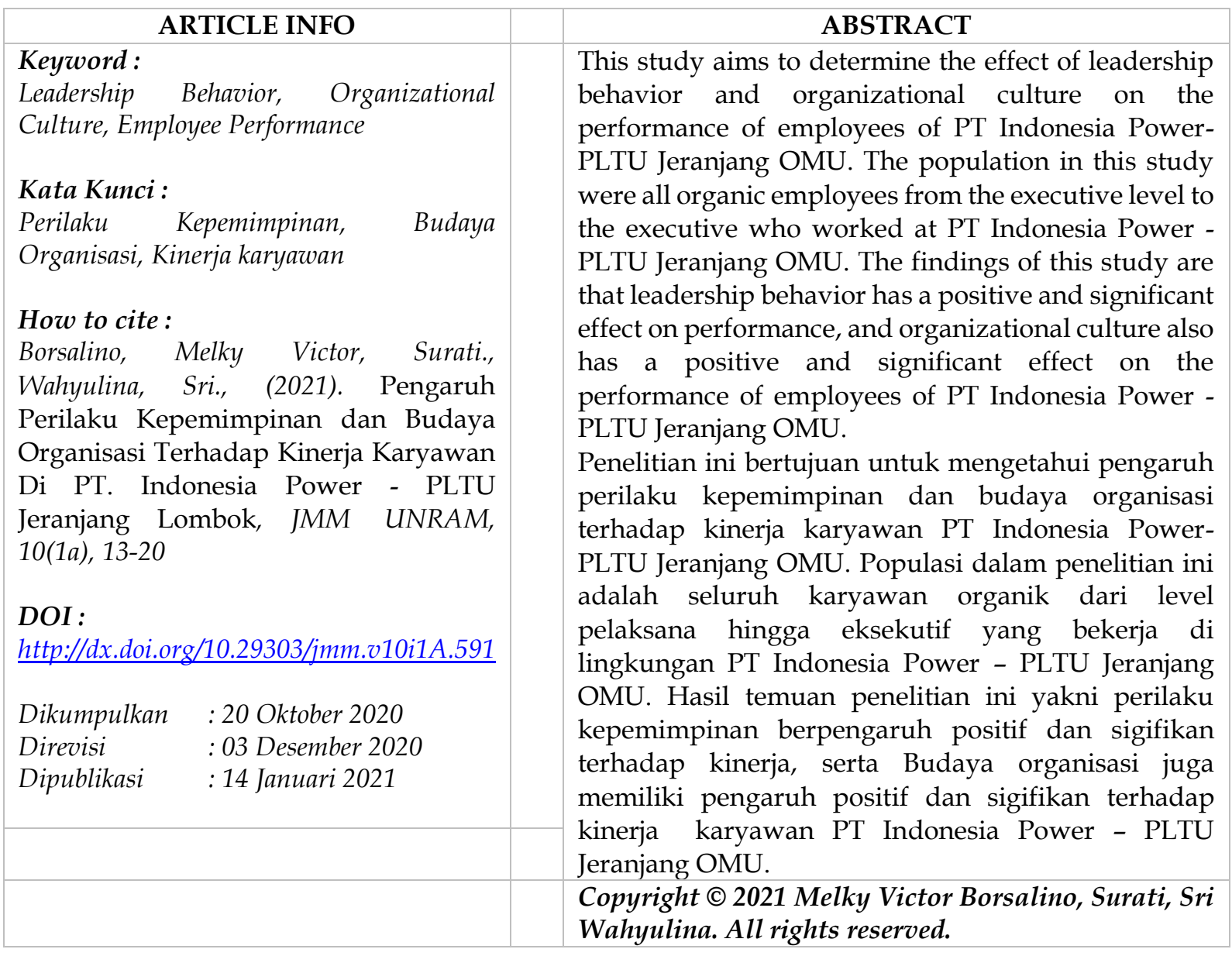




\section{PENDAHULUAN}

Aktivitas manusia modern tidak dapat terlepas dari penggunaan energi listrik. Hal ini merupakan dampak perkembangan ilmu pengetahuan dan teknologi yang sangat pesat menempatkan kebutuhan akan listrik menjadi salah satu kebutuhan utama disamping sandang, pangan dan papan. Di Indonesia, berdasarkan data dari Dinas Perencanaan Sistem PT. PLN (Persero) dan Tim Energi BPPT menyatakan bahwa total kebutuhan listrik di negara kita selama kurun waktu 17 tahun (2003 s.d. 2020) diproyeksikan tumbuh sebesar 6,5\% tiap tahun secara nasional, kebutuhan akan energi listrik terbesar pada sektor industri, sektor rumah tangga, sektor usaha, dan umum.

Perkembangan kebutuhan listrik yang semakin meningkat dari tahun ke tahun menyebabkan perusahaan penyedia listrik dituntut untuk selalu meningkatkan kinerjanya baik kualitas maupun mutu pelayanan agar mampu bersaing untuk menjadi lebih baik. Sumber daya manusia menjadi modal utama dari suatu organisasi yang berperan kunci dalam mencapai tujuan strategis. Salah satu hal yang menjamin keberlangsungan suatu perusahaan agar dapat beroperasi dengan efektif dan efisien adalah para pegawai yang berkinerja optimal. Ada begitu banyak pendapat para ahli dan peneliti mengenai kinerja itu sendiri salah satunya menyatakan bahwa kinerja adalah suatu tampilan keadaan secara utuh atas perusahaan selama periode waktu tertentu dan merupakan hasil atau prestasi yang dipengaruhi oleh kegiatan operasional perusahaan dalam memanfaatkan sumber-sumber daya yang dimiliki (Helfert, 1996).

Pencapaian tujuan organisasi merupakan fokus utama dibentuknya organisasi tersebut dimana peran kepemimpinan (leadership) sangat penting. Kepemimpinan dibutuhkan manusia, karena adanya suatu keterbatasan dan kelebihan-kelebihan tertentu pada manusia. Kemampuan manusia berbeda-beda ada yang memiliki kelebihan dan ada yang terbatas kemampuannya dalam memimpin. Di sini timbul kebutuhan akan pemimpin dan perilaku kepemimpinan.

Faktor eksternal berikutnya yang berpengaruh terhadap kinerja karyawan dan organisasi adalah Budaya organisasi. Budaya organisasi merupakan nilai-nilai yang berkembang dalam suatu organisasi, dimana nilai-nilai tersebut digunakan untuk mengarahkan perilaku anggota-anggota organisasi (Soedjono, 2005) selain itu budaya organisasi juga merupakan alat yang dapat menyatukan hubungan antara karyawan dengan organisasinya karena dengan adanya budaya tersebut maka membuat karyawan merasa bahwa dirinya merupakan bagian dari organisasi. Budaya organisasi yang kuat dalam suatu perusahaan akan berdampak langsung terhadap kinerja pegawainya maka jajaran manajemen wajib untuk menciptakan, mempertahankan, dan memperkuat nilai-nilai, norma-norma, peraturan-peraturan serta fungsi dan tujuan organisasi.

PT Indonesia Power sebagai salah satu anak perusahaan PT PLN Persero merupakan perusahaan yang bergerak dibidang ketenagalistrikan khususnya pembangkitan tenaga listrik yang berkembang sangat pesat dengan cakupan wilayah kerja hampir di seluruh Indonesia. Pada awal terbentuknya tanggal 3 Oktober 1995, sebagai perusahaan yang memproduksi listrik dan mempunyai beberapa unit pembangkit yang tersebar di seluruh Indonesia, telah dicanangkan visi perusahaan yang terus mengalami penyesuaian dan perubahan seiring dengan tuntutan internal dan eksternal sehingga melahirkan visi terbaru saat ini yaitu "Menjadi Perusahaan Energi Terbaik yang Tumbuh Berkelanjutan". Oleh sebab itu diperlukan pemimpin yang profesional dan berkompeten yang mampu memberikan pengaruh dan arahan kepada sumber daya yang ada agar tercapai tujuan dan visi perusahaan. PT. Indonesia Power beserta seluruh unit-unit kerjanya telah mengimplementasikan budaya tersendiri yang terbentuk dan dirangkum oleh para 
pendirinya berdasarkan rekam jejak dan pengalaman dalam menjalankan roda perusahaan yaitu Indonesia Power Way dan menganut tata nilai yang dikenal dengan IP-AKSI (Integritas, Profesional, Proaktif dan Sinergi).

Berdasarkan fenomena tersebut, penulis merasa tertarik untuk meneliti lebih dalam mengenai keterkaitan dan pengaruh perilaku kepemimpinan dan dimensi budaya organisasi terhadap kinerja karyawan khususnya pada PT Indonesia Power - PLTU Jeranjang Operation \& Maintenance Services Unit (OMU) yang beroperasi di pulau Lombok, provinsi Nusa Tenggara Barat (NTB).

\section{TINJAUAN PUSTAKA}

\subsection{Penelitian Terdahulu}

Terdapat beberapa hasil penelitian terdahulu yang membahas mengenai kinerja karyawan yang dipengaruhi oleh budaya organisasi dan perilaku kepemimpinan. Penelitian terhadap faktor-faktor yang mempengaruhi kinerja karyawan memang telah banyak dilakukan. Dari hasil penelitian tersebut nampak berbeda antara penelitian yang satu dengan penelitian yang lain. Diantaranya yaitu penelitian yang dilakukan oleh Brahmasari (2008) yang mengatakan bahwa motivasi dan budaya organisasi berpengaruh positif dan signifikan terhadap kepuasan kerja karyawan. Kemudian kepemimpinan berpengaruh negatif dan signifikan terhadap kepuasan kerja karyawan. Serta Membuktikan bahwa motivasi kerja berpengaruh positif dan signifikan terhadap kepuasan kerja tetapi belum tentu mempengaruhi kinerja perusahaan. Lalu membuktikan bahwa kepemimpinan berpengaruh positif dan signifikan terhadap kinerja perusahaan.

Penelititian yang dilakukan oleh Hartini (2014), yang meneliti signifikansi pengaruh perilaku kepemimpinan dan budaya organisasi secara partial dan simultan terhadap kinerja karyawan serta mencari variabel yang paling dominan mempengaruhi kinerja karyawan. Hasil penelitian yang dilakukan oleh Hartini memperkuat penelitian ini sebab Secara partial dan simultan terdapat pengaruh yang signifikan perilaku kepemimpinan dan budaya organisasi terhadap kinerja karyawan RSUD Kota Mataram. Variabel perilaku kepemimpinan merupakan faktor yang paling dominan mempengaruhi kinerja Pegawai Negri Sipil di RSUD Kota Mataram

\subsection{Perilaku Kepemimpinan}

Prof. Kimbal Young menyatakan bahwa kepemimpinan adalah suatu bentuk dominasi yang disengaja atau disadari oleh kemampuan pribadi yang mampu mendorong atau mengajak kepada orang lain dalam melakukan sesuatu berdasarkan atas penerimaan oleh kelompoknya dan mempunyai keahlian khusus secara tepat bagi situasi yang khusus. Kemudian S.P. Siagian menyatakan bahwa kepemimpinan adalah suatu keterampilan dan kemampuan dari seseorang yang telah menduduki suatu jabatan/posisi menjadi pimpinan dalam sebuah pekerjaan dalam mempengaruhi tindakan orang lain, terutama kepada bawahannya agar berpikir dan bertingkahlaku sedemikian rupa sehingga melalui tingkah laku positif ini dapat memberikan sumbangan yang nyata didalam pencapaian tujuan organisasi. Sedangkan teori yang dikemukakan oleh Robert. K. Greenleaf dalam "a Life of Servant Leadership" (1999) bahwa seorang Servant Leader dapat didefinisikan sebagai seorang pemimpin yang tujuan utamanya dalam memimpin adalah untuk melayani orang lain dengan berinvestasi dalam membangun kesejahteraan orang yang dipimpin untuk menyelesaikan tugas-tugas dan tujuan demi kebaikan bersama. Seorang pemimpin sejati merupakan seorang pemimpin yang motivasi utamanya dalam memimpin adalah untuk membantu orang lain yang berada dibawahnya (Spears, 2005). 


\subsection{Budaya Organisasi}

Robbins (2001:613), berpendapat bahwa budaya organisasi mempengaruhi isi keunggulan bersaing organisasi. Ketika faktor-faktor obyektif dipersepsikan sama oleh seluruh karyawan sehingga akan membentuk budaya organisasi. Budaya yang dihasilkan nanti dapat budaya yang kuat dan budaya yang lemah, selanjutnya akan berdampak pada kinerja dan kepuasan karyawan. Menurut Wibowo (2006:351), manfaat dari budaya organisasi yaitu sebagai berikut:

1) Membantu organisasi untuk mengarahkan sumber daya manusia pada pencapaian visi, misi, dan tujuan organisasi tersebut.

2) Meningkatkan dan memperkuat kekompakan tim antar berbagai departemen, divisi, atau unit dalam suatu organisasi sehingga dapat menjadi factor perekat yang mengikat antar personil dalam organisasi secara bersama-sama.

3) Membentuk perilaku staf dengan mendorong pencampuran core values dan perilaku yang diinginkan sehingga memungkinkan organisasi bekerja dengan lebih efisien dan efektif, meningkatkan konsistensi, menyelesaikan konflik dan memfasilitasi koordinasi dan kontrol.

4) Meningkatkan motivasi staf dengan memberi mereka perasaan untuk memiliki, loyalitas, kepercayaan dan nilai-nilai, dan mendorong untuk dapat berfikir positif tentang mereka dan organisasi.

5) Dapat memperbaiki perilaku dan motivasi sumber daya manusia sehingga mampu meningkatkan kinerjanya dan pada akhirnya dapat meningkatkan kinerja organisasi dalam pencapaian tujuan organisasi.

\subsection{Kinerja}

Kinerja merupakan suatu ukuran atas hasil kerja atau pencapaian seseorang dalam melaksanakan tugas dan tanggungjawabnya. Setiap perusahaan pasti ingin memiliki karyawan yang mempunyai kemampuan untuk menghasilkan suatu kinerja yang tinggi oleh sebab itu perusahaan selalu berupaya untuk meningkatkan kinerja dari setiap karyawan agar mendukung pencapaian target perusahaan secara korporasi. Kinerja adalah keluaran yang dihasilkan oleh fungsi-fungsi atau indikator-indikator suatu pekerjaan atau suatu profesi dalam waktu tertentu (Wirawan, 2009). Kinerja atau performansi dapat diartikan sebagai prestasi kerja, pelaksanaan kerja, pencapaian kerja, hasil kerja atau unjuk kerja (LAN, 2004:3). Sejalan dengan itu, Smith (1982:393) menyatakan bahwa kinerja merupakan hasil atau keluaran dari suatu proses yang bersifat kualitatif dan kuantitatif.

\subsection{Hubungan Antar Variabel}

\subsubsection{Hubungan Perilaku Kepemimpinan terhadap Kinerja Karyawan}

Pada penelitian Ali Muhtasom, H. Abdul Rahman Mus, Jamaluddin Bijang dan Baharuddin Latief (2017), menemukan bahwa Servant Leadership (X1) secara langsung berpengaruh positif dan signifikan terhadap kinerja $(Z)$ karyawan hotel berbintang di Makassar (coefficient value 0,293; p-value 0,033), hal ini berarti penerapan kepemimpinanpelayan dapat memberikan peningkatan terhadap kualitas pelayanan dengan indikator terkuat adalah persuasi (persuation).

\subsubsection{Hubungan Budaya organisasi terhadap Kinerja Karyawan}

Penelitian Ida Ayu Brahmasari dan Agus Suprayetno (2008), mendapatkan bukti bahwa budaya organisasi berpengaruh positif dan signifikan terhadap kinerja perusahaan, 
artinya bahwa budaya organisasi merupakan hasil dari suatu interaksi kebiasaan yang mempengaruhi sekelompok orang dalam lingkungan organisasinya, dapat membentuk suatu persepsi subyektif keseluruhan mengenai organisasi berdasarkan faktor-faktor seperti toleransi resiko, tekanan pada tim, dan dukungan orang, persepsi keseluruhan ini akan menjadi budaya atau kepribadian organisasi tersebut yang mampu mendukung dan mempengaruhi kinerja perusahaan serta dampak yang lebih besar pada budaya yang lebih kuat.

\section{METODE PENELITIAN}

\subsection{Jenis Penelitian}

Jenis penelitian ini adalah eksplanasi asosiatif, dimana data kuantitatif yang didapatkan melalui penelitian lapangan, dikaji dan dianalisis untuk mengetahui pengaruh ataupun hubungan antara dua variabel atau lebih (Sugiyono, 2003:14).

\subsection{Populasi dan Sampel Penelitian}

Populasi adalah wilayah generalisasi yang terdiri atas obyek/subyek yang mempunyai kualitas dan karakteristik tertentu yang ditetapkan peneliti yang kemudian ditarik kesimpulannya (Sugiyono, 2006). Populasi dalam penelitian ini adalah seluruh karyawan organik dari level pelaksana hingga eksekutif yang bekerja di lingkungan PT Indonesia Power - PLTU Jeranjang OMU. Menurut Sugiyono $(2008,116)$ "Sampel adalah sebagian dari jumlah dan karakteristik yang dimiliki oleh populasi tersebut". Sampel penelitian ini akan ditentukan berdasarkan jumlah populasi, apabila subyek kurang dari 100 lebih baik diambil semua hingga penelitiannya merupakan penelitian populasi (sensus) (Arikunto, 2008).

Berdasarkan dari data kepegawaian pada didapatkan bahwa jumlah populasi yang akan diteliti adalah sebanyak 46 orang sehingga penulis mengambil seluruhnya sebagai subyek penelitian.

\subsection{Alat Pengumpulan Data}

Alat pengumpulan data yang digunakan pada penelitian ini adalah kuesioner yaitu berupa pertanyaan tertulis yang digunakan untuk memperoleh informasi dari masingmasing responden dalam arti laporan tentang pribadinya atau hal-hal yang ia ketahui (Arikunto, 1998:140). Angket yang disajikan pada penelitian ini berisi pernyataan yang sudah baku yang disebarkan kepada para responden untuk mendapatkan data tentang "Pengaruh Perilaku Kepemimpinan dan Budaya Organisasi terhadap Kinerja Karyawan di PT Indonesia Power - PLTU Jeranjang Lombok".

\subsection{Metode Analisis}

Penelitian ini menggunakan analisis regresi berganda. Analisis regresi digunakan untuk melakukan regresi pada hubungan antara variabel bebas (perilaku kepemimpinan dan Budaya Organisasi) terhadap variabel terikat (Kinerja karyawan).

\section{PEMBAHASAN}


Hasil analisis regresi berganda untuk meramalkan variasi kinerja karyawan jika dipengaruhi oleh perilaku kepemimpinan dan budaya organisasi disajikan dalam tabel sebagai berikut

Tabel Hasil Regresi Berganda

Coefficients ${ }^{\mathrm{a}}$

\begin{tabular}{|c|c|c|c|c|c|c|c|c|}
\hline \multirow{2}{*}{\multicolumn{2}{|c|}{ Model }} & \multicolumn{2}{|c|}{$\begin{array}{l}\text { Unstandardized } \\
\text { Coefficients }\end{array}$} & \multirow{2}{*}{$\begin{array}{c}\begin{array}{c}\text { Standardize } \\
\mathrm{d} \\
\text { Coefficients }\end{array} \\
\text { Beta }\end{array}$} & \multirow[b]{2}{*}{$\mathrm{t}$} & \multirow[b]{2}{*}{ Sig. } & \multicolumn{2}{|c|}{ Collinearity Statistics } \\
\hline & & B & $\begin{array}{l}\text { Std. } \\
\text { Error }\end{array}$ & & & & Tolerance & VIF \\
\hline \multirow[t]{3}{*}{1} & $\begin{array}{l}\text { (Constan } \\
\text { t) }\end{array}$ & 2,641 & 405 & & 1,582 & 121 & & \\
\hline & $\mathrm{X} 1$ & 279 & 130 & 264 & 2,150 & 037 & ,532 & 1,879 \\
\hline & $\mathrm{X} 2$ & ,583 & 118 & 606 & 4,939 & ,000 &, 532 & 1,879 \\
\hline
\end{tabular}

a. Dependent Variable: $Y$

Berdasarkan hasil analisis regresi berganda pada tabel 4.11, diketahui nilai konstanta 2,641, nilai koefisien regresi variabel Perilaku kepemimpinan 0,279, nilai koefisien regresi dan variabel budaya organisasi 0,583 , maka persamaan regresi bergandanya adalah sebagai berikut :

$$
Y=2,641+0,279 X_{1}+0,583 X_{2}+e
$$

Dimana :

$$
\begin{array}{ll}
\mathrm{Y} & \text { : Kinerja } \\
\mathrm{X}_{1} & : \text { Perilaku kepemimpinan } \\
\mathrm{X}_{2} & \text { : Budaya Organisasi } \\
\mathrm{a} & \text { : Konstanta } \\
\mathrm{b}_{1} & : \text { Koefisien regresi Perilaku kepemimpinan } \\
\mathrm{b}_{2} & \text { :Koefisien regresi Budaya Organisasi } \\
\mathrm{e} & : \text { Error }
\end{array}
$$

\subsection{Pengaruh Perilaku Kepemimpinan Terhadap Kinerja Karyawan PT Indonesia Power- PLTU Jeranjang OMU}

Berdasarkan hasil analisis diketahui bahwa perilaku kepemimpinan berpengaruh positif dan signifikan terhadap kinerja karyawan PT Indonesia Power- PLTU Jeranjang OMU, sehingga hipotesis 1 yang menyatakan “Diduga Perilaku Kepemimpinan mempunyai pengaruh signifikan terhadap kinerja karyawan PT Indonesia Power - PLTU Jeranjang OMU" diterima.

Penelitian ini sejalan dengan hasil penelitian yang dilakukan oleh P. Herdiyanti Rise, Margono, S., \& Nimran, U., (2010), Hartini Baiq Ida Dini, (2014).

Hasil penelitian ini menunjukkan bahwa semakin tinggi perilaku kepemimpinan yang dimiliki karyawan PT Indonesia Power - PLTU Jeranjang OMU maka akan semakin baik kinerja dari karyawan PT Indonesia Power - PLTU Jeranjang OMU. Berdasarkan tanggapan responden dapat diketahui bahwa rata-rata karyawan PT Indonesia Power - PLTU Jeranjang OMU untuk melaksanakan tugas dan fungsi yang dibebankan kepada dirinya. Hal ini pun dapat dilihat, berdasarkan data empiris dari penelitian ini yang menunjukkan bahwa sebanyak 22 orang atau 47,8\% persen dari karyawan PT Indonesia Power - PLTU Jeranjang OMU memiliki pendidikan terakhir sarjana (S1), hal ini mengindikasikan bahwa karyawan PT Indonesia Power - PLTU Jeranjang OMU memiliki kompetensi untuk mengerjakan pekerjaannya karena pendidikan terakhir mereka adalah pendidikan tinggi. 


\subsection{Pengaruh Budaya Organisasi Terhadap Kinerja Karyawan PT Indonesia Power- PLTU Jeranjang OMU}

Berdasarkan hasil analisis diketahui bahwa budaya organisasi berpengaruh positif dan signifikan terhadap kinerja karyawan PT Indonesia Power- PLTU Jeranjang OMU, sehingga hipotesis 2 yang menyatakan "Diduga budaya organisasi mempunyai pengaruh signifikan terhadap kinerja karyawan PT Indonesia Power - PLTU Jeranjang OMU" diterima.

Penelitian ini sejalan dengan hasil penelitian yang dilakukan oleh P. Herdiyanti Rise, Margono, S., \& Nimran, U., (2010), Hartini Baiq Ida Dini, (2014). Menurut Robbins budaya organisasi mempengaruhi isi keunggulan bersaing organisasi. Ketika faktor-faktor obyektif dipersepsikan sama oleh seluruh karyawan sehingga akan membentuk budaya organisasi. Budaya yang dihasilkan nanti dapat budaya yang kuat dan budaya yang lemah, selanjutnya akan berdampak pada kinerja dan kepuasan karyawan.

Hasil penelitian ini menunjukkan bahwa semakin tinggi budaya organisasi yang dimiliki karyawan PT Indonesia Power - PLTU Jeranjang OMU maka akan semakin baik kinerja dari karyawan PT Indonesia Power - PLTU Jeranjang OMU.

\section{KESIMPULAN}

Berdasarkan hasil analisis regresi linier berganda yang telah dilakukan dengan SPSS versi 23.0, dapat ditarik kesimpulan bahwa perilaku Kepemimpinan memiliki pengaruh positif dan sigifikan terhadap kinerja, artinya semakin tinggi perilaku kepemimpinan yang dimiliki karyawan PT Indonesia Power - PLTU Jeranjang OMU maka akan semakin baik kinerja dari karyawan PT Indonesia Power - PLTU Jeranjang OMU. Kemudian budaya organisasi juga memiliki pengaruh positif dan sigifikan terhadap kinerja, artinya semakin baik budaya organisasi yang diberikan kepada karyawan PT Indonesia Power - PLTU Jeranjang OMU maka akan meningkatkan kinerja karyawan PT Indonesia Power - PLTU Jeranjang OMU.

Berdasarkan nilai koefisien determinasi diketahui bahwa pengaruh perilaku kepemimpinan dan budaya organisasi terhadap kinerja karyawan PT Indonesia Power PLTU Jeranjang OMU sebesar 63,9 persen, sedangkan 36,1 persen dipengaruhi oleh faktor lain di luar model.

\section{DAFTAR PUSTAKA}

Abdullah, H.M. Ma'ruf. 2015. Metodologi Penelitian Kuantitatif. Cetakan 1. Yogyakarta: Aswaja Presindo

Arikunto, Suharsimi. 2006. Metodologi penelitian. Yogyakarta: Bina Aksara Suharsimi. 2008. Prosedur Penelitian suatu Pendekatan Praktik. Edisi Revisi. Jakarta: Rhineka Cipta

Gibson, J.L. Ivancevich, J.M., Donely, J.H. 2012. Organisasi: Perilaku, Struktur, Proses, Jilid-1 edisi ke-5. Jakarta: Erlangga

Greenleaf, Robert K. 1999. Reflection On Leadership (Renungan tentang Kepemimpinan). Batam: Interaksara

Lembaga Administrasi Negara. 2004. Pedoman Penyusunan Laporan Akuntabilitas Kinerja Instansi Pemerintah. Jakarta 2004. Penilain Kinerja. Jakarta: Spimnas LAN RI

Riduwan. 2008. Skala Pengukuran Variabel-Variabel Penelitian. Bandung: Alfabeta 2009. Metode E Teknik Menyusun Proposal Penelitian. Cetakan ke-6. Bandung: Alfabeta 
Ritonga, Rahman. 1997. Statistika untuk Penelitian Psikologi dan Penelitian. Jakarta: Lembaga Penerbit Fakultas Ekonomi UI

Robbins, Stephen P. 2003. Perilaku Organsisasi: Konsep, Kontroversi, Aplikasi. Jilid 1. Jakarta: Prenhallindo

Robins, \& Judge. 2015. Perilaku Organisasi. ed.16. Jakarta: Salemba Empat Simamora, Henry. 2004. Manajemen Sumber Daya Manusia. Jakarta: STIE YKPN

Siregar, Syofian. 2013. Metode Penelitian Kuantitatif. Edisi pertama. Jakarta: Fajar Interpratama Mandiri

Sondang, S.P. 2005. Teori dan Praktik Kepemimpinan. Jakarta: Rineka Cipta Sugiyono. 2003. Metode Penelitian Bisnis. Bandung. Pusat Bahasa Depdiknas 2004. Metode Penelitian Bisnis. Cetakan ke-6. Bandung: Alfabeta 2011. Metode Penelitian Kuantitatif Kualitatif \& RND. Bandung: Alfabeta 2013. Metode Penelitian Manajemen. Bandung: Alfabeta

Wirawan. 2008. Budaya dan Iklim Organisasi: Teori, Aplikasi dan Penelitian. Jakarta: Salemba 